\title{
Who Owns Academic Work? Battling for Control of Intellectual Property
}

\author{
by Corynne McSherry \\ Harvard University Press, 275pp, \\ $\$ 29.95,2001$
}

\author{
Reviewed by SHeLdon Krimsky \\ Department of Urban \& \\ Environmental Policy \& Planning \\ Tufts University \\ Medford, Massachusetts, USA
}

The academic world has been struggling with, adjusting to, and exploiting the new rules of intellectual property. There was a time, not too long ago, when professors could make multiple copies of a published journal article and distribute them to their classes. Today, copyright laws require that permission must be granted and fees paid to reproduce multiple copies of scholarly work used for educational purposes. A cottage industry has evolved that obtains permissions for classroom use of articles and packages them at a premium cost.

And there was a time, not too long ago, when scientists shared biological materials and genetic data freely with colleagues, only for the asking. But that too changed when gene sequences, microorganisms and research animals became intellectual property. The scope of intellectual property claims encompasses computer algorithms, university lectures and even surgical techniques.

Corynne McSherry's first book, Who Owns Academic Work? Battling for Control of Intellectual Property, provides a legal and cultural perspective on new property regimes in academia. The author draws from a wealth of scholarship that includes the history of property law, discourse analysis and science studies to help the reader make sense out of three legal cases that form the core of the book's analysis. The cases are worth summarizing.

The first case involves a young starquality radiologist who-in collaboration with her mentor, the chief of nuclear medicine at a prestigious medical school-developed a syllabus for a course in nuclear medicine. Several years later the young radiologist produced a new version of the syllabus under her name. Meanwhile, her mentor adapted her new version under his name. Since both parties participated in the development of the early syllabus, each claimed the right to adapt and use the syllabus under their respective names. The young radiologist sued her mentor for plagiarism. McSherry explores the rights of copyright ownership, a term she describes as a "boundary object", which, loosely interpreted, is a concept with ambiguous meanings that supports competing legal claims and social constructions.

In a second case, an enterprising optometrist collaborates with a UC Berkeley alumnus to form an academic note-taking business. In the mid-1960s, students at UCLA were hired to audit and take notes in 150 courses. The detailed lecture notes were published, advertised in campus publications, and sold to students planning to enroll in the courses. A professor sued the note-taking entrepreneurs for violating his intellectual property rights. McSherry takes us through the maze of legal arguments that address the status of a professor's lectures. If they are someone's property, then whose? The professor or the university? Perhaps it is public speech and therefore part of the commons. Harvard University stopped one of its mediaphilic law professors from selling his guest lectures that were videotaped at another university. Many professors have Internet sites on university servers in which they include papers in progress, published works, lecture notes, and audio or video presentations. McSherry's second case, litigated nearly forty years ago, brings these issues into sharper focus.

The third case addresses the boundaries of ownership of scientific data. Two post-doctoral candidates contested each other's claim as the discoverer of a set of procedures for crystallizing a protein. One of the scientists claimed that the procedure was stolen from her laboratory by a former colleague, who gave the technique to a pharmaceutical company. The case explores the elusive concept of data, and its ownership, control and status as intellectual property. McSherry informs us that courts are hes- itant to rule on conflicts of data ownership, preferring that they be resolved within the science community. But the self-governance of science sometimes breaks down. Recently, a graduate student at the University of South Florida served time in jail rather than turn over his patent to his professor who claimed that it was stolen intellectual property.

Since the passage of the Bayh-Dole Act in 1980, Congress has made its own voice heard on the transfer of intellectual property from publicly funded research. There is more to litigate now that data from publicly funded research and its economic value is transferred to private hands.

The book neither resolves boundary disputes of intellectual property nor makes recommendations. It does shed light on the complexity of the problems and gives us alternative constructions based on a set of dualisms such as the gift (meaning public commons) economy versus market economy of knowledge production. McSherry succeeds in answering the question: "What contests for meaning arise when academics position themselves as knowledge owners and how are these contests resolved?" for the cases in question. There is much in this book for those who seek a historical and legal background to contemporary disputes over knowledge production and ownership in academia.

Areas left unexamined are the profound cultural changes taking place in the university including changes in the ethos of science resulting from the intense commodification of knowledge, issues awaiting exploration within the discourse of boundary domains. The patenting of genomic information impedes research in important clinical areas. The genome has ostensibly been colonized and there is no legislated research exemption. More than any of the cases cited in the work, this state of affairs fulfills the book jacket's publicity imperative, which asserts that the battle over intellectual property "ought to deeply trouble everyone who cares about the academy." Reading Who Owns Academic Work? is a first step to understanding the troubling consequences of superimposing the market economy on knowledge production. 